\title{
pH-Dependent Bioavailability, Speciation, and Phytotoxicity of Tungsten (W) in Soil Affect Growth and Molybdoenzyme Activity of Nodulated Soybeans
}

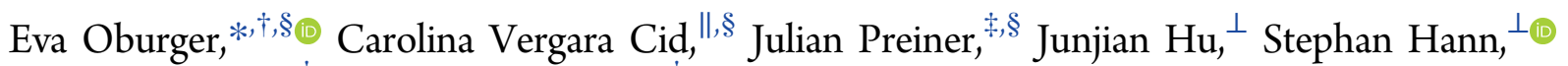 \\ Wolfgang Wanek, ${ }^{\dagger}$ and Andreas Richter ${ }^{\dagger}$
}

\begin{abstract}
${ }^{\dagger}$ Department of Microbiology and Ecosystem Science, Division of Terrestrial Ecosystem Research and ${ }^{\ddagger}$ Department of Ecogenomics and Systems Biology, University of Vienna, Althanstrasse 14, A-1090 Vienna, Austria

${ }^{\S}$ BOKU, Department of Forest and Soil Sciences, University of Natural Resources and Life Sciences, Konrad-Lorenz Strasse 24, A-3430 Tulln, Austria

"Faculty of Physical and Natural Sciences, Multidisciplinary Institute of Plant Biology, Pollution and Bioindicator Section, National University of Cordoba, Avenida Velez Sarsfield 1611, X5016CGA Cordoba, Argentina

${ }^{\perp}$ BOKU, Department of Chemistry, University of Natural Resources and Life Sciences, Muthgasse 18, A-1190 Vienna, Austria
\end{abstract}

\section{Supporting Information}

\begin{abstract}
Increasing use of tungsten (W)-based products opened new pathways for $\mathrm{W}$ into environmental systems. Due to its chemical alikeness with molybdenum (Mo), W is expected to behave similarly to its "twin element", Mo; however, our knowledge of the behavior of $\mathrm{W}$ in the plant-soil environment remains inadequate. The aim of this study was to investigate plant growth as well as $\mathrm{W}$ and nutrient uptake depending on soil chemical properties such as soil $\mathrm{pH}$ and texture. Soybean (Glycine max cv. Primus) was grown on two acidic soils differing in soil texture that were either kept at their natural soil $\mathrm{pH}(\mathrm{pH}$ of $4.5-5)$ or limed $(\mathrm{pH}$ of $\geq 7$ ) and amended with increasing concentrations of metallic $\mathrm{W}$ (control and 500 and $5000 \mathrm{mg} \mathrm{kg}^{-1}$ ). In addition, the activity of molybdoenzymes involved in $\mathrm{N}$ assimilation (nitrate reductase) and symbiotic $\mathrm{N}_{2}$ fixation (nitrogenase) was also investigated. Our results showed that the risk of $\mathrm{W}$ entering the food web was significantly greater in high-pH soils due to increased solubility of mainly monomeric W. The effect of soil texture on W solubility and phytoavailability was less pronounced compared to soil $\mathrm{pH}$. Particularly at intermediate W additions (W $500 \mathrm{mg}$ $\mathrm{kg}^{-1}$ ), symbiotic nitrogen fixation was able to compensate for reduced leaf nitrate reductase activity. When W soil solution concentrations became too toxic (W $5000 \mathrm{mg} \mathrm{kg}^{-1}$ ), nodulation was more strongly inhibited than nitrogenase activity in the few nodules formed, suggesting a more-efficient detoxification and compartmentalization mechanism in nodules than in soybean leaves. The increasing presence of polymeric $\mathrm{W}$ species observed in low-pH soils spiked with high $\mathrm{W}$ concentrations resulted in decreased W uptake. Simultaneously, polymeric W species had an overall negative effect on nutrient assimilation and plant growth, suggesting a greater phytotoxicity of $\mathrm{W}$ polymers. Our study demonstrates the importance of accounting for soil $\mathrm{pH}$ in risk assessment studies of $\mathrm{W}$ in the plant-soil environment, something that has been completely neglected in the past.
\end{abstract}

\section{INTRODUCTION}

Tungsten $(\mathrm{W})$ is a transition metal that resides in the chromium (Cr) group (group VI) of the periodic table along with $\mathrm{Cr}$ and molybdenum (Mo). Compared with other metals, $\mathrm{W}$ abundance in the Earth's crust is very low, ranking $54^{\text {th }}$ and $18^{\text {th }}$ in the overall element and metal abundance lists, respectively. ${ }^{1}$ Nevertheless, a variety of $\mathrm{W}$ minerals is known with four being of economic importance (wolframite, (Fe, $\mathrm{Mn}) \mathrm{WO}_{4}$; hübnerite, $\mathrm{MnWO}_{4}$; ferberite, $\mathrm{FeWO}_{4}$; and scheelite, $\left.\mathrm{CaWO}_{4}\right)$.

Increasing the industrial and military use of $\mathrm{W}$-based products, ranging from household appliances to high-end technology goods, ${ }^{2}$ opened new pathways for $\mathrm{W}$ into environmental systems. Main routes of entry into the environment include the emission and discharge of $\mathrm{W}$ containing waste products by $\mathrm{W}$-production plants, military activities, $\mathrm{W}$ tire studs, and road abrasion, coal combustion, and soil fertilizer application. ${ }^{2-4}$ In particular, the use of $\mathrm{W}$ ammunition has been shown to lead to significantly elevated $\mathrm{W}$ concentrations in soil (up to $2000 \mathrm{mg} \mathrm{kg}{ }^{-1}$ ). ${ }^{5}$ Recent assessments indicate that the anthropogenic contribution to $\mathrm{W}$ mobilization in the environment amounts to about $30 \%$ of the total global surface fluxes but would increase to about $60 \%$ if W

Received: December 18, 2017

Revised: March 8, 2018

Accepted: April 27, 2018

Published: April 27, 2018 
transport with human-induced soil erosion and Aeolian dust is included. ${ }^{6}$ These numbers clearly show the importance of soil processes in controlling the global fluxes of W. Average background concentrations of $\mathrm{W}$ in soil range from $0.1-2.7 \mathrm{mg}$ $\mathrm{kg}^{-1}$; however, reported $\mathrm{W}$ concentrations in soils near mining or smelting sites, war zones (Gulf War region), or military firing ranges exceed background thresholds by 10 - to 2000 -fold. ${ }^{2,7} \mathrm{~A}$ survey from China revealed significant $\mathrm{W}$ bioaccumulation in rice grown on agricultural fields adjacent to a $\mathrm{W}$ mine, ${ }^{8}$ further highlighting the need for a better understanding of the biogeochemical behavior of $\mathrm{W}$ in the environment.

In environmental systems, $\mathrm{W}$ occurs as thermodynamically stable oxyanion, tungstate $\left(\mathrm{WO}_{4}{ }^{2-}\right)$, with $\mathrm{W}$ in its highest oxidation number $\left(6^{+}\right)$. Experimental data suggest that the behavior of monomeric $\mathrm{W}$ in soil is comparable to that of other oxoanions like molybdate or phosphate $\left(\mathrm{P}_{\mathrm{i}}\right)$. In a leaching column experiment with soil amended with metallic $\mathrm{W}$, Bednar et al. ${ }^{9}$ showed that $\mathrm{W}$ leaching increased with increasing $\mathrm{pH}$ of the leachate solution as well as in the presence of competing anions (phosphate) and humic acids. Gustafsson ${ }^{10}$ compared $\mathrm{W}$ and Mo sorption onto ferrihydrite across a wide $\mathrm{pH}$ range and observed that the decrease in sorption with increasing $\mathrm{pH}$ was less pronounced for $\mathrm{W}$ than for Mo, indicating a higher sorption affinity of $\mathrm{W}$. While knowledge of the chemical and environmental behavior of $\mathrm{W}$ in soil remains limited, these results suggest that solubility and consequently plant uptake strongly depend on soil $\mathrm{pH}$.

Recent, but limited, toxicological studies in soil showed that plants and soil organisms are relatively tolerant to elevated W concentrations. Bamford et al., ${ }^{11}$ for example, found no effect on the survival and reproduction of earthworms at $\mathrm{W}$ concentrations of $586 \mathrm{mg} \mathrm{kg}^{-1}$ soil (artificial soil, $\mathrm{pH} 6.5$ ), while different tolerance levels were observed for different plant species (oat (Avena sativa) > radish (Raphanus sativus) > lettuce (Lactuca sativa)). High tolerance often coincides with high biomass accumulation, composing a considerable yet understudied entry pathway of $\mathrm{W}$ into the food web, and suitable methods of predicting $\mathrm{W}$ plant uptake from soil have not yet been investigated.

Tungsten is, in many ways, the twin element of molybdenum (Mo). Both elements, Mo and $\mathrm{W}$, belong to the $\mathrm{Cr}$ group, but unlike chromium, the two heavier elements possess equal atomic $\left(1.4 \times 10^{-10} \mathrm{~m}\right)$ and ionic $\left(0.68 \times 10^{-10} \mathrm{~m}\right)$ radii, similar electronegativity ( 1.4 for $\mathrm{W}, 1.3$ for $\mathrm{Mo}$ ), and the same range of oxidation states $(-2$ to +6$)$ and coordination numbers (5-9). ${ }^{1}$ Consequently, $\mathrm{W}$ and Mo also show similar redox and coordination chemistries in both structural and functional aspects. In higher plants, Mo, unlike $\mathrm{W}$, is an essential micronutrient. Being a cofactor of enzymes involved in nitrate assimilation (nitrate reductase (NR)) and symbiotic nitrogen $\left(\mathrm{N}_{2}\right)$ fixation (nitrogenase), ${ }^{12}$ Mo plays a key role in plant $\mathrm{N}$ nutrition. It is well-known that certain metalloenzymes are not absolutely metal specific, and negative effects of $\mathrm{W}$ on molybdoenzyme activity in plants and prokaryotes have been repeatedly demonstrated. ${ }^{13-16}$ Nevertheless, the uptake and incorporation of $\mathrm{W}$ as well as its effects on plant metabolism are still not well understood, and there is a lack of studies linking bioavailability of $\mathrm{W}$ to plant physiological performance.

The aim of this study was, therefore, to investigate $\mathrm{W}$ solubility and plant uptake depending on soil chemical properties such as soil $\mathrm{pH}$ and texture by growing soybeans (Glycine max cv. Primus) in two natural acidic soils differing in soil texture (silt clay loam and sandy loam, World Reference
Base of Soil (WRB), Food and Agriculture Organization of the United Nations) that were either kept at their natural soil $\mathrm{pH}$ or limed $\left(2.5 \% \mathrm{CaCO}_{3}\right)$. Each combination of soil $\mathrm{pH}$ and texture was spiked with increasing concentration of metallic $\mathrm{W}$ (control and 500 and $5000 \mathrm{mg} \mathrm{kg}^{-1}$ ). The effects of soil-pHdependent $\mathrm{W}$ phytoavailability and speciation on plant nutrition and growth as well as the activity of molybdoenzymes involved in $\mathrm{N}$ assimilation (nitrate reductase) and symbiotic $\mathrm{N}_{2}$ fixation (nitrogenase) were investigated.

\section{MATERIALS AND METHODS}

Experimental Soils. Experimental soils were collected from Siebenlinden $\left(48^{\circ} 40.513^{\prime} \mathrm{N}, 14^{\circ} 59.933^{\prime} \mathrm{E}\right)$ and Litschau $\left(48^{\circ} 57.37167^{\prime} \mathrm{N}, 15^{\circ} 3.95167^{\prime} \mathrm{E}\right)$ in the Waldviertel area in Lower Austria. Both soils evolved from granite rock and are classified as acidic Cambisol. Based on soil texture analysis (Table 1), the soil from Siebenlinden will from here on be

\section{Table 1. General Properties of the Experimental Soils ${ }^{a}$}

\begin{tabular}{llcc}
\multicolumn{1}{c}{ soil properties } & \multicolumn{1}{c}{ unit } & clay & sand \\
$\mathrm{pH}$ natural soil $\left(\mathrm{CaCl}_{2}\right)$ & & $5.03 \pm 0.23$ & $4.50 \pm 0.09$ \\
$\mathrm{pH}$ limed $\left(\mathrm{CaCl}_{2}\right)$ & & $7.44 \pm 0.10$ & $7.02 \pm 0.05$ \\
$\mathrm{CEC}$ & $\mathrm{mmolc} \mathrm{kg}^{-1}$ & $94.7 \pm 1.50^{b}$ & $58.7 \pm 0.52^{b}$ \\
$\mathrm{AAO}-$ extractable Fe & $\mathrm{g} \mathrm{kg}^{-1}$ & $6.31 \pm 0.13^{b}$ & $7.68 \pm 0.43^{b}$ \\
$\mathrm{AAO}-$-extractable Al & $\mathrm{g} \mathrm{kg}^{-1}$ & $3.05 \pm 0.07^{b}$ & $4.39 \pm 0.22^{b}$ \\
textural class $(\mathrm{WRB})$ & & silt clay loam & sandy loam \\
sand & percent & $13.7 \pm 0.20$ & $53.7 \pm 0.86$ \\
silt & percent & $65.3 \pm 2.06$ & $37.6 \pm 3.26$ \\
clay & percent & $21.1 \pm 2.26$ & $8.74 \pm 2.40$ \\
SOC & $\mathrm{g} \mathrm{kg}^{-1}$ & $33.9 \pm 1.31^{b}$ & $31.2 \pm 0.20^{b}$ \\
$\mathrm{~N}$ total & $\mathrm{g} \mathrm{kg}^{-1}$ & $0.23 \pm 0.00^{b}$ & $0.31 \pm 0.02^{b}$
\end{tabular}

${ }^{a}$ Values represent means $\pm \mathrm{SE}(n=3) .{ }^{b}$ Statistical differences between soils (ANOVA, DGC, $p<0.05$ ). AAO, acid ammonium oxalateextractable $\mathrm{Fe}$ and $\mathrm{Al}$ in natural soils. SOC, soil organic carbon.

referred to as sand soil, and the soil originating from Litschau will be referred to as clay soil. Soils were air-dried at an ambient temperature and passed through a $4 \mathrm{~mm}$ sieve. Liming is a common agricultural practice for raising soil $\mathrm{pH}$ and improving nutrient availability. Half of the soil material was therefore amended with $\mathrm{CaCO}_{3}$ (calcium carbonate precipitated, puriss, Sigma-Aldrich) to a final concentration of $2.5 \%$ to achieve a high-pH (limed) treatment, and the other half of the soil was directly used as a low-pH (acidic) counterpart. To simulate anthropogenic driven $\mathrm{W}$ entries into the environment, e.g., via ammunition or abrasion of cutting and drilling tools, metallic W powder (tungsten powder, $<2 \mu \mathrm{m}, 99.95+$, Inframat Advanced Materials) was directly added to aliquots of the acidic and limed soils to final concentrations of 500 and $5000 \mathrm{mg} \mathrm{kg}^{-1} \mathrm{~W}$ (dry weight ( $\mathrm{dwt}$ ) basis) resulting in a total of 12 soil treatments, including controls. The soils were then incubated at $60 \%$ maximum water holding capacity (MWHC) for 11 months at $25{ }^{\circ} \mathrm{C}$ in black plastic boxes loosely covered with wooden boards to allow the metallic W powder to interact with the soil matrix (i.e., aging). Previous studies demonstrated that metal phytotoxicity of freshly amended soils in laboratory studies was significantly higher compared with corresponding aged or field contaminated soils. ${ }^{17}$ Once a month, soils were mixed by hand and moisture content was gravimetrically checked and, if necessary, adjusted every month during the incubation period. General soil properties of the experimental soils are shown in Table 1, with $\mathrm{pH}$ being determined in $0.01 \mathrm{M} \mathrm{CaCl}_{2}$, ${ }^{18}$ acid 
ammonium oxalate (AAO)-extractable $\mathrm{Fe}$ and $\mathrm{Al}$ being determined according to Loeppert and Inskeep ${ }^{19}$ cationexchange capacity (CEC) following $\mathrm{BaCl}_{2}$ extraction, ${ }^{20}$ and soil organic carbon and total soil $\mathrm{N}$ being analyzed by an elemental analyzer (Macro Cube Vario, Elementar).

Pot Experiment. After the pre-incubation period, soils were air-dried, homogenized, and sieved $(4 \mathrm{~mm})$. The pots $(2 \mathrm{~L})$ were filled with $2 \mathrm{~kg}$ soil each (dwt) and watered from the bottom to field capacity. A total of four replicates per soil treatment were prepared. Soybean seeds were soaked in distilled water for $6 \mathrm{~h}$ and then germinated on water saturated perlite for 7 days. Thereafter, seedlings of the same size were inoculated with Bradyrhizobium japonicum (Radicin Soya, JOST $\mathrm{GmbH}$, Iserlohn, Germany) by immersing the roots in a $7.5 \%$ $\mathrm{v} / \mathrm{v}$ Radicin solution for $45 \mathrm{~min}^{21,22}$ Immediately after the inoculation procedure, three seedlings were transplanted into each pot. Inoculum solution $(6 \mathrm{~mL})$ was additionally added to each pot right after transplanting. ${ }^{23}$ The pot experiment was carried out in a greenhouse with average temperatures of 17.6 ${ }^{\circ} \mathrm{C}$ and $34.9{ }^{\circ} \mathrm{C}$ (night and day, respectively) and a $12 \mathrm{~h}$ photoperiod $\left(320 \mu \mathrm{mol} \mathrm{m} \mathrm{m}^{-2} \mathrm{~s}^{-1}\right.$ photosynthetic active radiation). Pots were watered with low amounts of water twice daily using an automatic dripping irrigation, avoiding the leaching of soil solution but replenishing evapotranspirational losses. After 3 weeks of soil growth, cytosolic nitrate reductase activity of the leaves was assayed for all treatments (further details see below). Plants were grown on both limed soils with the highest $\mathrm{W}$ addition $\left(5000 \mathrm{mg} \mathrm{kg}{ }^{-1}\right)$ shortly thereafter and were harvested upon plant death. Plant biomass from all other treatments was harvested 6 weeks after transplanting (R4, full pod stage). ${ }^{24}$ Roots, shoots, and nodules were separated and pooled to a composite sample of the three individual plants in each pot; shoots were washed with deionized water; and roots were consecutively sonicated first in a $5 \mathrm{mM} \mathrm{CaCl} \mathrm{Cl}_{2}$ solution and then in deionized water for 5 min each. Biomass was then dried at $60{ }^{\circ} \mathrm{C}$ for 7 days for dry mass assessment. Plant tissue was acid-digested using an adapted procedure by Pöykiö et al. ${ }^{25}$ Briefly, $5 \mathrm{~mL}$ of $65 \% \mathrm{HNO}_{3}$ (pro analysi, Sigma) and $1 \mathrm{~mL}$ of $\mathrm{H}_{2} \mathrm{O}_{2}$ (30\% in $\mathrm{H}_{2} \mathrm{O}$, TraceSELECT Ultra, Suprapur) were added to $0.2 \mathrm{~g}$ of ground plant material in long glass tubes equipped with cooling tubes, and the suspension was digested in an open heating block with the following temperature program: $65{ }^{\circ} \mathrm{C}(25 \mathrm{~min}), 110{ }^{\circ} \mathrm{C}(10 \mathrm{~min})$, and $155^{\circ} \mathrm{C}(158$ min). Total $\mathrm{W}$ and nutrient concentrations in the digests were quantified by inductively coupled plasma mass spectrometry (ICP-MS, Elan DRCe 9000, PerkinElmer; W, Mo, Cu, Zn, Ni, and $\mathrm{Cr}$ ) and inductively coupled plasma atomic emission spectrometry (ICP-OES, Optima 8300, PerkinElmer; P, K, S, $\mathrm{Mg}$, $\mathrm{Ca}$, and $\mathrm{Fe}$ ); for details, see the Supporting Information.

Cytosolic Nitrate Reductase Assay. After 3 weeks of growth, leaf subsamples ( $0.2 \mathrm{~g}$ fresh weight) were collected ( $n$ $=4$ ) from all pots, and nitrate reductase (NR) activity was determined according to an adapted assay by Sanderson and Cocking $^{26}$ and Stöhr et al. ${ }^{27}$ The selected time point still allowed the analysis of the plants from the limed W 5000 treatment, which died shortly after the enzyme assay was conducted. The detailed procedure is described in the Supporting Information. Plants continued to grow for another 3 weeks until the final harvest with the exception of the limed W 5000 treatment.

Symbiotic $\mathbf{N}_{\mathbf{2}}$ Fixation. Nodule activity was assessed on the basis of natural $\mathrm{N}$ isotope fractionation between plant organs according to Wanek and Arndt. ${ }^{28}$ Briefly, dried and finely ground plant tissues were weighed into tin capsules and analyzed for $\mathrm{N}$ content and ${ }^{15} \mathrm{~N}$-to- ${ }^{14} \mathrm{~N}$ ratios by isotope ratio mass spectrometry (IRMS); for details, see the Supporting Information. The difference between above-ground (shoot) and below-ground (roots and nodules) $\delta^{15} \mathrm{~N}$ signatures, $\Delta \delta^{15} \mathrm{~N}_{\mathrm{bg}}$ (eq 1), was used to estimate the proportion of total plant $\mathrm{N}$ derived from the atmosphere (percent NdfA) according to the relationship reported by Wanek and $\mathrm{Arndt}^{28}$ (eq 2) for soybeans:

$$
\begin{aligned}
& \Delta \delta^{15} \mathrm{~N}_{\mathrm{bg}}=\delta^{15} \mathrm{~N}_{\text {shoots }}-\delta^{15} \mathrm{~N}_{\text {roots plus nodules }} \\
& \operatorname{NdfA}(\%)=19.8-8.9 \Delta \delta^{15} \mathrm{~N}_{\mathrm{bg}}
\end{aligned}
$$

Nodule fixation activity (grams of nitrogen fixed per gram of nodule dry weight) was calculated according to eq 3 :

$$
\text { nodule fixation activity }=\frac{\operatorname{NdfA}(\%) \times N_{\text {plant total }}}{100 \times M_{\text {nodule }}}
$$

with $N_{\text {plant total }}$ being the total amount of $\mathrm{N}$ accumulated during the growth period (milligrams of $\mathrm{N}$ ) and $M_{\text {nodule }}$ being the dry nodule biomass (in milligrams).

Soil-Solution Analysis. Dried, pre-incubated (11 months), unplanted, experimental soils were incubated in triplicate for 24 $\mathrm{h}$ at a 1:0.5 soil-to-solution ratio (SSR; wt/v) with deionized water in the dark at $25^{\circ} \mathrm{C}$, and soil solution was obtained after centrifugation at $21000 \mathrm{~g}$ for $15 \mathrm{~min} .{ }^{29}$ The SSR was chosen to be close to natural soil moisture conditions and still get sufficient quantities of soil solution for further processing. The supernatant was immediately filtered through $0.45 \mu \mathrm{m}$ syringe filters (Whatman GDX, nylon). An aliquot of the $0.45 \mu \mathrm{m}$ filtrate from all soil and $\mathrm{W}$ treatments was acidified to a final concentration of $2 \% \mathrm{HNO}_{3} / 0.02 \% \mathrm{HF}$ and analyzed by ICPMS (Elan DRCe 9000, PerkinElmer). To verify the increasing presence of polymeric $\mathrm{W}$ species at low soil $\mathrm{pH}$ and high $\mathrm{W}$ concentrations, $0.5 \mathrm{~mL}$ aliquots of the W 5000 soils were passed through either a 30 or a $10 \mathrm{kDa}$ ultrafiltration device (Merck) via centrifugation for $1 \mathrm{~h}$ at $9727 \mathrm{~g}$ at $4{ }^{\circ} \mathrm{C}$. We expected that $10 \mathrm{kDa}$ cutoff filtration leads to the separation of monomers and oligomers from larger polymeric tungsten species, whereas $30 \mathrm{kDa}$ filters retain only the fraction of long chained polymers. The $0.45 \mu \mathrm{m}$ filtration was regarded as a cleanup step corresponding to $100 \%$ recovery of all dissolved tungsten species present in the sample. After ultrafiltration, the filtrates from the different filtration steps $(0.45 \mu \mathrm{m}$ and 10 and $30 \mathrm{kDa})$ were appropriately diluted, acidified $\left(2 \% \mathrm{HNO}_{3} /\right.$ $0.02 \% \mathrm{HF}$ final concentration), and analyzed by inductively coupled plasma sector field mass spectrometry (ICP-SFMS, ELEMENT 2, Thermo Fisher Scientific).

Statistical and Data Analysis. Data were analyzed by three-way ANOVA using a linear mixed model and the DGC post-hoc test ${ }^{30}$ to investigate potential effects and interactions of tungsten concentration (W), soil $\mathrm{pH}(\mathrm{pH})$, and soil mineralogy and texture (soil). Nodule biomass, elemental concentrations in nodules, percent NdfA, and nodule fixation activity were only subjected to a one-way ANOVA because the missing data due to a lack of nodule formation or to insufficient biomass did not allow for the application of a linear mixed model with interactions. Normality and homoscedasticity were checked and corrected if required. Results were considered statistically significant at $p<0.05$. Correlation analysis (Pearson) was carried out to test the potential positive or negative effects of $\mathrm{W}$ on plant nutrition within each $\mathrm{pH}$ 

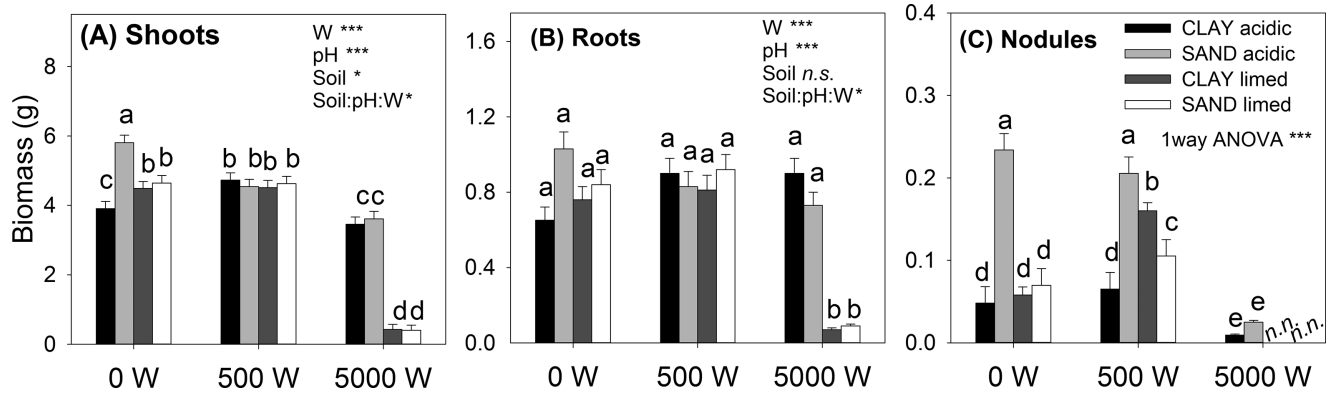

Figure 1. (A) Shoot, (B) root, and (C) nodule biomass of soybean (Glycine max cv. Primus) grown on the experimental soils with different W concentrations for 6 weeks except for soybean grown on the limed W 5000 soils that died 3 weeks after soil exposure. Values represent means \pm SE $(n=4)$. Letters indicate significant differences across the different soil and all $\mathrm{W}$ treatments (three-way ANOVA, post-hoc: DGC). Level of significance is depicted as a single asterisk for $p<0.05$, double asterisks for $p<0.01$, triple asterisks for $p<0.001$, n.s. for "not significant", and n.n. for "no nodules formed".
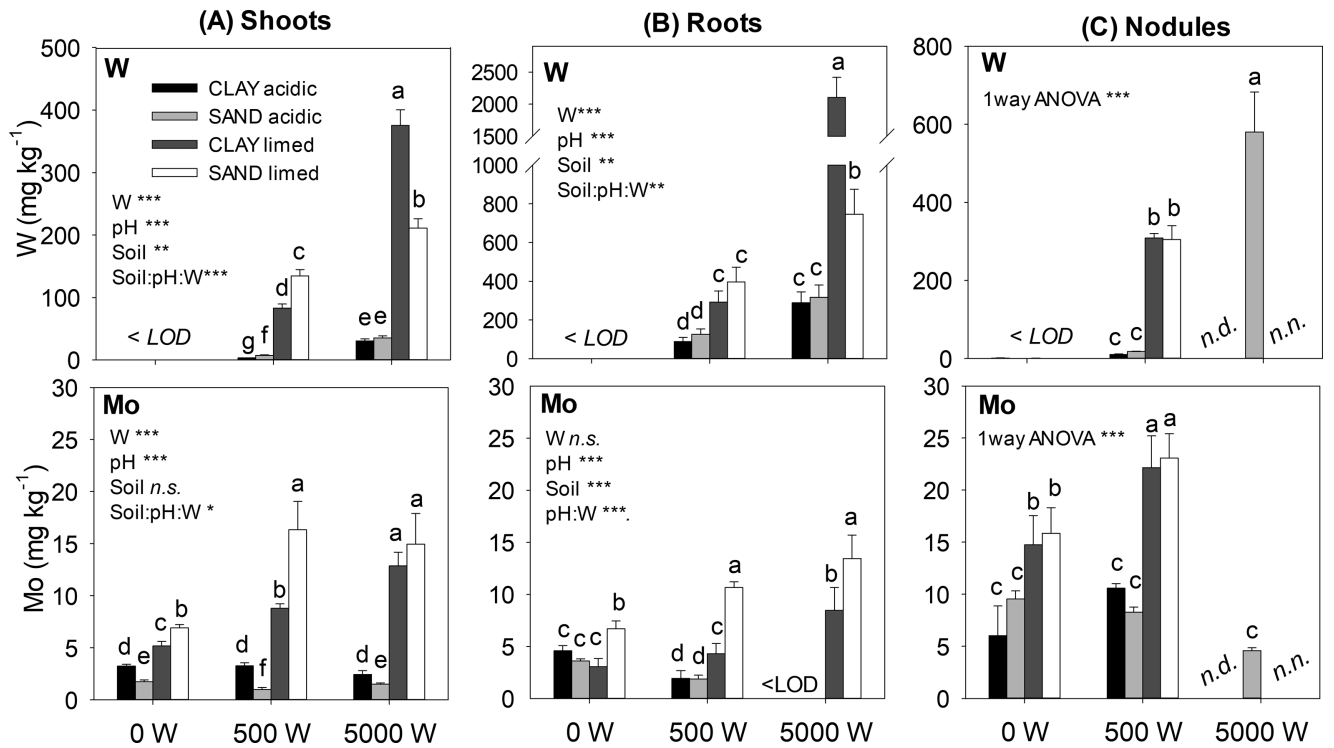

Figure 2. Tungsten (W) and molybdenum (Mo) concentrations in (A) shoots, (B) roots and (C) nodules of soybeans grown on the different experimental soils. Values represent means \pm SE $(n=4)$. Letters indicate significant differences across the different soil and $\mathrm{W}$ treatments $($ three-way ANOVA except for nodules as missing data only the allowed analysis by one-way ANOVA; post-hoc: DGC). Level of significance is depicted as a single asterisk for $p<0.05$, double asterisks for $p<0.01$, triple asterisks for $p<0.001$, n.s. for not significant, n.n. for "no nodules formed", n.d. for "not determined due to insufficient biomass", and LOD for "limit of detection".

treatment (limed and acidic). All statistical tests were carried out using the software Infostat coupled with $\mathrm{R}^{31}$ (version 2015). Detailed statistical results are presented in the Supporting Information.

\section{RESULTS}

Effect of W on Soybean Biomass Production. Plants grown on the limed $5000 \mathrm{mg} \mathrm{kg}^{-1} \mathrm{~W}$ soils died about 3 weeks after transplanting. The limed W 5000 treatments were still included for completeness; however, the difference in plant physiological stage at harvest compared with all other treatments needs to be considered accordingly. Except for the high-W treatment (W 5000) in the limed soils, soybean root biomass was not affected by the addition of different $W$ concentrations. Small but significant differences in shoot biomass were observed (Figure 1A,B). Interestingly, already in the control treatments the shoot biomass was lowest in the acidic clay soil and highest in the acidic sand soil compared with intermediate values in the limed clay and sand control soils. While this difference was diminished in the presence of intermediate $\mathrm{W}$ concentrations (W 500), the application of
$5000 \mathrm{mg} \mathrm{kg}^{-1} \mathrm{~W}$ led to a significant reduction in shoot biomass both in acidic soils compared to the intermediate $\mathrm{W}$ application and, moreso, in limed soils. Unlike root and shoot biomasses ( $p$ $<0.05$ ), nodule biomass $(p<0.001)$ was more strongly affected by soil type, $\mathrm{pH}$, and $\mathrm{W}$ phytoavailability (Figure $1 \mathrm{C}$ ). In the control treatments, liming had a strong negative effect on nodule biomass in the sand soil, an effect that was not found in the clay soil. The presence of intermediate $\mathrm{W}$ concentrations (W 500) increased nodule biomass in both limed soils but not in the acidic soils in comparison with the respective controls. In the acidic W 5000 soils; however, nodule biomass was strongly decreased compared with the controls and the W 500 treatment, and no nodules were formed by soybeans grown on the limed W 5000 soils, demonstrating a strong inhibition of nodule initiation/differentiation in the presence of very high soluble $\mathrm{W}$ concentrations.

W and Mo Uptake by Soybeans Depending on Soil Properties. As expected, soil $\mathrm{pH}$ had a significant effect on $\mathrm{W}$ and Mo solubility and, consequently, phytoavailability $(p<$ 0.001 ), while the effect of soil texture and mineralogy was less strong though still mostly significant (W roots and shoots, $p<$ 
Table 2. Soil Solution Concentrations of $\mathrm{W}$ and Mo in the Different Experimental Soils ${ }^{a}$

\begin{tabular}{|c|c|c|c|c|}
\hline \multirow[b]{2}{*}{ treatment } & \multicolumn{2}{|c|}{$\mathrm{W}\left(\mathrm{mg} \mathrm{L}^{-1}\right)$} & \multicolumn{2}{|c|}{$\operatorname{Mo}\left(\mu \mathrm{g} \mathrm{L}^{-1}\right)$} \\
\hline & clay & sand & clay & sand \\
\hline acidic W 0 & $<\mathrm{LOQ}$ & $<$ LOQ & $0.04 \pm 0.01^{\mathrm{d}}$ & $0.02 \pm 0.04^{\mathrm{d}}$ \\
\hline acidic W 500 & $4 \times 10^{-3} \pm 1 \times 10^{-4 e}$ & $0.01 \pm 2 \times 10^{-4 \mathrm{e}}$ & $<$ LOQ & $0.17 \pm 0.10^{\mathrm{d}}$ \\
\hline acidic W 5000 & $24.8 \pm 0.98^{c}$ & $9.74 \pm 2.04^{\mathrm{d}}$ & $0.58 \pm 0.06^{\mathrm{d}}$ & $0.50 \pm 0.05^{\mathrm{d}}$ \\
\hline limed W 0 & $<$ LOQ & $<$ LOQ & $5.36 \pm 0.22^{\mathrm{d}}$ & $15.3 \pm 1.85^{\mathrm{c}}$ \\
\hline limed W 500 & $2.43 \pm 0.05^{\mathrm{e}}$ & $3.34 \pm 0.04^{\mathrm{e}}$ & $11.87 \pm 0.47^{c}$ & $66.9 \pm 1.26^{\mathrm{b}}$ \\
\hline limed W 5000 & $126.1 \pm 3.7^{\mathrm{aa}}$ & $113.7 \pm 1.85^{\mathrm{b}}$ & $12.88 \pm 0.43^{c}$ & $98.1 \pm 7.14^{\mathrm{a}}$ \\
\hline
\end{tabular}

${ }^{a}$ Values represent means $\pm \mathrm{SE}(n=3)$. Letters represent statistical differences across the different soils, $\mathrm{pH}$, and W treatments (ANOVA, DGC, $p<$ $0.0001)$. LOQ limit of quantification.

0.01; Mo shoots, not significant; Mo roots, $p<0.001$; Figure 2 and Table 2). Consequently, the uptake of $\mathrm{W}$ (and Mo) was higher in the limed soils compared with their acidic counterparts for both $\mathrm{W}$ additions, with $\mathrm{W}$ root and shoot tissue concentrations increasing by an average factor of $4 \pm 2$ and $15 \pm 9$ (mean $\pm \mathrm{SD}$ ), respectively (Figure 2A,B). W tissue concentrations $\geq 211$ (shoot) and $\geq 747$ (root) $\mathrm{mg} \mathrm{kg}^{-1}$, respectively, led to the death of soybean seedlings after 3 weeks of growth in the limed W 5000 experimental soils. At shoot and root $W$ concentrations of $135 \pm 10($ mean $\pm S E)$ and $398 \pm 76$ $\mathrm{mg} \mathrm{kg}^{-1}$ (limed sand, W 500), respectively, soybean biomass production was not affected (Figures 1 and 2). As was observed for shoot biomass (Figure 1A), shoot W concentrations were significantly lower in the acidic W 5000 soils than in the limed W 500 soils despite higher water-soluble W concentrations measured in soil saturation extracts of the acidic W 5000 soils (in comparison to limed W 500) (Table 2; for a direct comparison of limed W 500 versus acidic W 5000, see Figure S2). The concurrence of decreased shoot biomass and W tissue concentrations in the acidic W 5000 treatments in comparison to the limed W 500 soils therefore suggests a change in W speciation and toxicity at low $\mathrm{pH}$ and high $\mathrm{W}$ concentrations. Nodule W accumulation was 7-9 times lower compared with root $\mathrm{W}$ concentrations in the acidic W 500 soils but was similar (nodules: $310 \pm 11 \mathrm{mg} \mathrm{kg}^{-1} \mathrm{~W}$ ) to root $\mathrm{W}$ in the corresponding limed W 500 treatments. However, in the acidic W 5000 sand soil, nodule W $\left(581 \pm 103 \mathrm{mg} \mathrm{kg}^{-1}\right)$ exceeded root $\mathrm{W}\left(318 \pm 63 \mathrm{mg} \mathrm{kg}^{-1}\right)$ concentrations by a factor of approximately 2 (Figure 2C), which was accompanied by a significant decrease in nodule biomass (Figure 1C) compared with both the control and W 500 acidic sand. Nodule biomass was insufficient for $\mathrm{W}$ and nutrient analysis in the acidic $\mathrm{W}$ 5000 clay soil, and no nodules were formed in the limed W 5000 soils.

Plant uptake of molybdenum, which was kept at natural background concentrations, showed similar trends as W. As with W, the shoot, root, and nodule Mo concentrations were higher in the limed soil treatments (Figure 2). Mo shoot and root concentrations were higher in the limed sand soil compared to the limed clay soil across the different $\mathrm{W}$ treatments (excluding shoots in limed W 5000 soils), while Mo concentrations in nodules were similar in clay and sand soils within each $\mathrm{pH}$ and $\mathrm{W}$ treatment (excluding limed W 5000 because no nodules were formed). A strong positive correlation between $\mathrm{W}$ and Mo root and particularly shoot concentrations was found in the limed soils (Table 3). In the acidic soils, increasing $\mathrm{W}$ amendments either had no effect (shoots) or a strong negative effect (roots) on Mo tissue concentrations. While no differences in nodule Mo were found in the acidic soils across all $\mathrm{W}$ treatments, liming resulted in a significant
Table 3. Pearson Correlation Coefficients Revealing the SoilpH-Dependent Effects of $\mathrm{W}$ on Nutrient Concentration in Soybean Roots and Shoots ${ }^{a}$

\begin{tabular}{|c|c|c|c|c|}
\hline & \multicolumn{4}{|c|}{ effect of W on nutrients in soybean (excluding limed W 5000 soils) } \\
\hline & $\begin{array}{c}\mathrm{W} \text { in acidic } \\
\text { soils, } N=24\end{array}$ & $\begin{array}{c}\mathrm{W} \text { in limed } \\
\text { soils, } N=16\end{array}$ & $\begin{array}{c}\mathrm{W} \text { in acidic } \\
\text { soils, } N=24\end{array}$ & $\begin{array}{c}\mathrm{W} \text { in limed } \\
\text { soils, } N=16\end{array}$ \\
\hline & \multicolumn{2}{|c|}{ shoots } & \multicolumn{2}{|c|}{ roots } \\
\hline $\mathrm{P}$ & -0.79 & -0.15 & 0.11 & 0.56 \\
\hline $\mathrm{Ca}$ & -0.94 & -0.41 & -0.3 & -0.09 \\
\hline $\mathrm{K}$ & -0.36 & 0.12 & -0.22 & 0.26 \\
\hline $\mathrm{Mg}$ & -0.62 & -0.26 & -0.58 & 0.04 \\
\hline$S$ & -0.61 & -0.24 & -0.66 & 0.12 \\
\hline $\mathrm{Fe}$ & -0.52 & -0.67 & 0.00 & 0.7 \\
\hline Mo & -0.27 & 0.84 & -0.85 & 0.54 \\
\hline $\mathrm{Cr}$ & -0.63 & -0.6 & -0.81 & -0.21 \\
\hline Co & -0.74 & -0.23 & -0.32 & -0.26 \\
\hline $\mathrm{Ni}$ & -0.49 & -0.53 & -0.42 & -0.26 \\
\hline $\mathrm{Cu}$ & -0.85 & -0.64 & -0.7 & -0.63 \\
\hline $\mathrm{Zn}$ & -0.65 & -0.16 & -0.22 & -0.75 \\
\hline
\end{tabular}

${ }^{a}$ Results from the limed W 5000 soils were excluded due to the different plant developmental stages at harvest. Significant correlations $(p<0.05)$ are highlighted in bold.

increase in the W 500 soils. Molybdenum concentrations in nodules were higher than in roots or shoots across all soils and treatments except for acidic clay control soil $(p<0.01$, Table S4).

Effect of $\mathrm{W}$ on the Activity of Molybdoenzymes Involved in Plant $\mathbf{N}$ Nutrition. Nitrate reductase (NR) activity in soybean leaves, symbiotic $\mathrm{N}_{2}$ fixation (estimated as percentage of $\mathrm{N}$ derived from the atmosphere and as nodule fixation activity) and total plant $\mathrm{N}$ were significantly affected by the addition of 500 and $5000 \mathrm{mg} \mathrm{W} \mathrm{kg}{ }^{-1}$ soil. Except for the limed W 5000 soils in which no nodules were formed, complex, interdependent responses of molybdoenzyme activities (Figure $3 \mathrm{~A}, \mathrm{D})$ and nodule biomass formation (Figure 1C) resulted in different contributions of symbiotic $\mathrm{N}_{2}$ fixation to total plant $\mathrm{N}$ nutrition (Figure 3B) while maintaining total plant $\mathrm{N}$ at or even above control levels (acidic W 500 clay soil), irrespective of soil type, $\mathrm{pH}$, and $\mathrm{W}$ addition (Figure $3 \mathrm{C}$ ). NR activity generally decreased with increasing $\mathrm{W}$ concentrations in all soil treatments except for the acidic sand, in which it remained constant across the different $\mathrm{W}$ addition levels (W 0, W 500, and W 5000; Figure 3A). Moreover, NR activity was lower in the acidic sand soil control (W 0 ) compared with the other control soils, a finding that was accompanied by a significantly higher nodule biomass resulting in a higher contribution of symbiotically fixed $\mathrm{N}$ (percent $\mathrm{NdfA}$ ) to total plant $\mathrm{N}$ acquisition (Figure 3A-C). 




Figure 3. (A) Nitrate reductase (NR) activity in soybean leaves, (B) estimation of the percentage of plant $\mathrm{N}$ derived from the atmosphere (\%NdfA), (C) total $\mathrm{N}$ accumulated in the biomass (in milligrams) during plant growth, and (D) nodule fixation activity (grams $\mathrm{N}$ fixed per gram nodule dwt.). Values represent means \pm SE $(n=4)$. Letters indicate significant differences across the different soil and $\mathrm{W}$ treatments (three-way ANOVA; post-hoc: DGC). Level of significance is depicted as a single asterisk for $p<0.05$, double asterisks for $p<$ 0.01 , triple asterisks for $p<0.001$, and n.s. for "not significant".

In the limed W 500 soils, a decrease in NR activity was compensated by increased nodule biomass, keeping biomass production and total plant $\mathrm{N}$ accumulation at control levels despite the significantly increased $\mathrm{W}$ concentrations in nodules. Nodulation was more strongly enhanced in the limed W 500 clay soil compared to the limed W 500 sand, resulting in an additional increase in the proportion of symbiotically derived plant N (percent NdfA) in the limed W 500 clay soil (Figures $1 \mathrm{C}$ and $3 \mathrm{~A}-\mathrm{D})$.

Rather contrasting results were found in the acidic soil treatments. For the acidic clay soil, the total plant $\mathrm{N}$ was higher in the W 500 treatment compared to the control despite a decrease in NR activity together with constant nodule biomass, nodule fixation activity, and percent NdfA. At the highest W addition (5000 mg kg-1), NR activity decreased in the acidic clay soil to levels comparable to those of the dying plants from the limed W 5000 treatments. However, this was compensated by a sharp increase in nodule fixation activity increasing the percent NdfA and keeping $\mathrm{N}$ accumulation comparable with control treatments (Figures $1 \mathrm{C}$ and $3 \mathrm{~A}-\mathrm{D}$ ).
In the acidic sand, neither NR activity nor nodule fixation activity were affected by increasing $\mathrm{W}$ concentrations (Figure $3 A, D)$. Because nodule biomass was not affected by the addition of $500 \mathrm{mg} \mathrm{kg}^{-1} \mathrm{~W}$, percent NdfA and total plant $\mathrm{N}$ remained at control levels in the acidic W500 sand soil. At W 5000, a sharp drop in nodule biomass (Figure 1C) resulted in a decreased contribution of symbiotically fixed $\mathrm{N}$ (percent NdfA) in the acidic sand soil, decreasing total plant $\mathrm{N}$ acquisition during the experimental growth period to the levels of the limed control and W 500 soils (Figure 3B,C).

Effect of $\mathbf{W}$ on Plant Nutrition Other than $\mathrm{N}$ and Mo. Soil $\mathrm{pH}$ and soil type also significantly affected root and shoot tissue concentrations of some but not all nutrients, while the addition of increasing $\mathrm{W}$ concentrations had a significant effect on soybean plant nutrition, irrespective of specific nutrient or plant tissue type (Tables S1-3). Despite numerous changes, no clear trends could be observed for all other investigated macroand micronutrients upon the addition of $500 \mathrm{mg} \mathrm{W} \mathrm{kg}^{-1}$ soil (Tables S1-3). However, shoot concentrations of all investigated nutrients significantly decreased in the acidic $\mathrm{W}$ 5000 soils, with particularly large changes present in $\mathrm{P}, \mathrm{Ca}$, and Fe shoot concentrations (2-3 times less than the respective control; Figure 4 and Tables 3 and S1). Excluding the limed W 5000 soils, correlation analysis further revealed a significant negative effect of $\mathrm{W}$ on almost all investigated nutrients in the acidic soils as well as on shoot $\mathrm{Fe}, \mathrm{Cr}, \mathrm{Ni}$, and $\mathrm{Cu}$ in both $\mathrm{pH}$ treatments (Table 3). Unlike shoots, root nutrient concentrations showed no consistent trends upon $\mathrm{W}$ addition across the different $\mathrm{pH}$ treatments.

W Speciation. Ultrafiltration of the soil solutions of the W 5000 soils after 11 months of pre-equilibration with different molecular weight cut-offs $(30$ and $10 \mathrm{kDa})$ revealed that both soil $\mathrm{pH}$ and texture significantly affected $\mathrm{W}$ speciation $(p<$ 0.0001 ), with only $32 \%$ and $54 \%$ of $\mathrm{W}$ being recovered after ultrafiltration with $10 \mathrm{kDa}$ (monomeric $\mathrm{W}$ and small $\mathrm{W}$ polymers) in the acidic clay and sand soil, respectively (Table 4). On the contrary, W recovery in the limed W 5000 soils was similar ( $83 \%$ in sand soil and $85 \%$ in clay soil) after $10 \mathrm{kD}$ filtration, clearly indicating a higher degree of polymerization under acidic conditions (acidic soils having 46-68\% versus limed soils having $15-17 \%$ of $>10 \mathrm{kDa})$.

\section{DISCUSSION}

W Phytoavailability and Phytotoxicity. The small number of studies on $\mathrm{W}$ phytoavailability and phytotoxicity in soils or hydroponics report a wide range of $\mathrm{W}$ concentrations $\left(81-\geq 3900 \mathrm{mg} \mathrm{kg}^{-1}\right.$ and $\geq 100 \mu \mathrm{M} \mathrm{W}$, respectively) at which
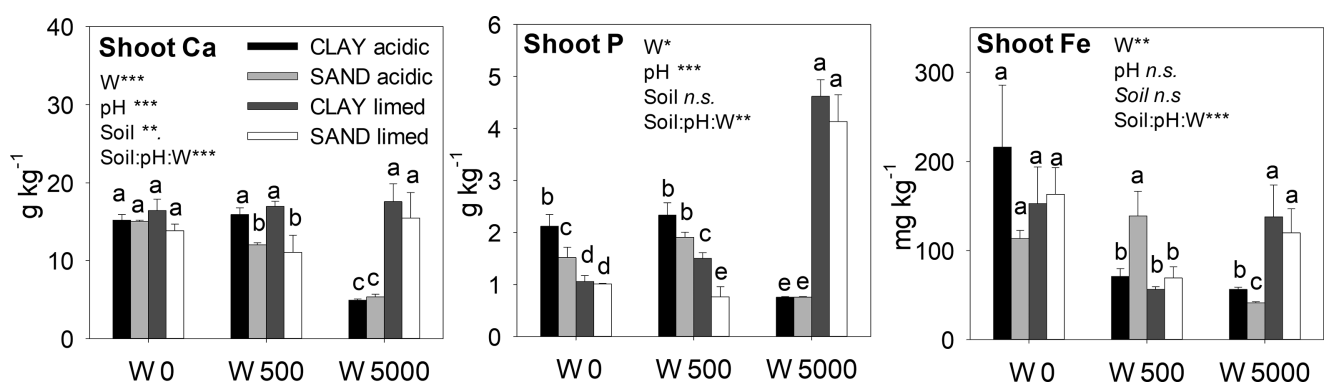

Figure 4. Concentrations of $\mathrm{P}, \mathrm{Ca}$ (grams per kilogram), and $\mathrm{Fe}$ (milligrams per kilogram) in the shoots of soybeans grown on the different experimental soils. Values represent means \pm SE $(n=4)$. Letters indicate significant differences across the different soils and $\mathrm{W}$ treatments $($ threeway ANOVA; post-hoc: DGC). Level of significance is depicted as a single asterisk for $p<0.05$, double asterisks for $p<0.01$, triple asterisks for $p<$ 0.001 , and n.s. for "not significant". 
Table 4. Absolute Recovery of $\mathrm{W}$ in the Soil Solution (in Milligrams per Liter) after Ultracentrifugation with Different Size Cut-Offs $(0.45 \mu \mathrm{m} \text { and } 30 \text { and } 10 \mathrm{kDa})^{a}$

$\begin{array}{lccc}\text { W } 5000 & <10 \mathrm{kDa} & 10-30 \mathrm{kDa} & 30 \mathrm{kDa}-0.45 \mu \mathrm{m} \\ & \text { mean } \pm \mathrm{SE}\left(\mathrm{mg} \mathrm{L}^{-1} \mathrm{~W}\right) \text { (percent of total recovered) } \\ \text { acidic clay } & 7.90 \pm 0.44^{\mathrm{t}}(32 \%) & 10.0 \pm 0.56(40 \%) & 6.86 \pm 0.38^{\mathrm{b}}(28 \%) \\ \text { acidic sand } & 5.26 \pm 1.56^{\mathrm{t}}(54 \%) & 3.01 \pm 0.89^{\mathrm{z}}(31 \%) & 1.47 \pm 0.43^{\mathrm{c}}(15 \%) \\ \text { limed clay } & 108 \pm 4.53^{\mathrm{r}}(85 \%) & 7.42 \pm 0.31^{\mathrm{y}}(6 \%) & 11.0 \pm 0.46^{\mathrm{a}}(9 \%) \\ \text { limed sand } & 94.4 \pm 2.17^{\mathrm{s}}(83 \%) & 7.37 \pm 0.17^{\mathrm{y}}(6 \%) & 12.0 \pm 0.28^{\mathrm{a}}(11 \%) \\ { }^{a} \text { Values represent means } \pm \mathrm{SE}(n=3) . \text { Different letter groups indicate } \\ \text { significant differences across the different soil treatments within one } \\ \text { filtration size class (one-way ANOVA, DGC, } p<0.001) .\end{array}$

plant growth was impaired. ${ }^{7,8,11,13,32-34}$ While the differences in the $\mathrm{W}$ concentration thresholds in hydroponic studies can be simply related to species-specific tolerance mechanisms, the interpretation of soil-based studies is more complex as particularly soil $\mathrm{pH}$ significantly determines $\mathrm{W}$ solubility and speciation' (Tables 2 and 4; also see the Polymeric W Species section) and, consequently, phytoavailability. However, to date, the effect of soil properties on W solubility has been ignored in most soil-based studies investigating $\mathrm{W}$ plant uptake.

By liming $\left(2.5 \% \mathrm{CaCO}_{3}\right)$ naturally acidic soils spiked with different metallic $\mathrm{W}$ concentrations (500 and $5000 \mathrm{mg} \mathrm{kg}^{-1}$ ), we showed that $\mathrm{W}$ plant uptake significantly increased with increasing soil $\mathrm{pH}$ and $\mathrm{W}$ solubility (Figure 2 and Table 2 ). In the W 500 treatment, liming enhanced W shoot tissue concentrations 18-24 times compared with their acidic counterparts, with biomass production being negatively affected by neither soil $\mathrm{pH}$ nor medium $\mathrm{W}$ addition. The crucial role of soil $\mathrm{pH}$ on $\mathrm{W}$ solubility is even more clearly demonstrated in the W 5000 treatment, in which soluble W concentrations became phytotoxic in the limed experimental soils, triggering plant death after 3 weeks of soil exposure and preventing nodule growth. We also observed that the $\mathrm{W}$ concentration range between absence of visible growth effects $(135 \pm 10 \mathrm{mg}$ $\left.\mathrm{kg}^{-1}\right)$ and seedling death $\left(221 \pm 15 \mathrm{mg} \mathrm{kg}^{-1}\right.$, limed sand) was rather narrow for soil grown soybean shoots (Figures 1 and 2). With respect to other plant species for which $\mathrm{W}$ uptake was investigated, soybean plans seem to be rather sensitive toward high $\mathrm{W}$ concentrations. Cereals appear to be more tolerant, with reported W leaf concentrations of $202 \mathrm{mg} \mathrm{kg}^{-1}$ for rye grass grown for 9 months on a W-contaminated soil $(1000 \mathrm{mg}$ $\left.\mathrm{kg}^{-1}\right), 35$ although, unfortunately, no data on soil $\mathrm{pH}$ were presented in this study.

As previously reported, ${ }^{33,36}$ low soluble $\mathrm{W}$ concentrations can have a positive effect on plant biomass production; however, this was only observed for shoot biomass in the acidic W 500 clay, the soil with the lowest soluble W concentrations (Figure 1 and Table 2). In this treatment, nodule biomass (Figure 1) and nodule fixation activity (Figure 3D) were slightly higher than in the control soil. Even though these differences were not statistically significant, they may have been sufficient to result in the observed shoot biomass increase. Other than that, increases in root $\mathrm{P}, \mathrm{Fe}$, and $\mathrm{Zn}$ concentrations (Table S2) may also have stimulated shoot biomass production in the acidic W 500 clay soil.

Our results clearly show that, like for many other elements, total soil concentrations are a poor indicator for $\mathrm{W}$ phytoavailability in soil. As for other oxoanions, the increase in $\mathrm{W}$ solubility with increasing $\mathrm{pH}$ can be attributed to an increase in negative surface potential due to the deprotonation of mineral surfaces at high $\mathrm{pH}$ leading to decreased retention of anions by the soil matrix. ${ }^{10,37}$ Soils with a high clay content generally show a higher sorption potential for both anions and cations than soils with a coarser soil texture due to the higher specific surface area. Unexpectedly, at the highest $\mathrm{W}$ addition rate $\left(5000 \mathrm{mg} \mathrm{kg}^{-1}\right), \mathrm{W}$ solubility was significantly higher in the clay soil than in the sand soil irrespective of $\mathrm{pH}$ treatment, while no differences were observed for the W 500 treatments (Table 2). A recent study demonstrated that, particularly at high $\mathrm{W}$ concentrations, $\mathrm{W}$ sorption to metal oxides such as boehmite occurred in polymeric forms across a wide $\mathrm{pH}$ range ( $\mathrm{pH}$ 4-8), explaining the continuous $\mathrm{W}$ immobilization without an apparent maximum in sorption. ${ }^{38}$ Consequently, we attribute the lower W solubility in the W 5000 sand soil to the higher abundance of positively charged metal oxides in the sand soil (Table 1). Correspondingly higher $\mathrm{W}$ plant uptake in the W 5000 clay soil was only observed for the limed treatments, while no differences in $\mathrm{W}$ tissue concentrations were found in the acidic W 5000 soils (Figure 2A,B) as a result of $\mathrm{W}$ polymer formation (Table 4; also see the Polymeric $\mathrm{W}$ Species section and Figure S2).

Polymeric W Species. Like Mo, W is known to polymerize at increasing concentrations and at low $\mathrm{pH}^{39}$ however, $\mathrm{W}$ speciation in soil solution is still not completely understood. It is generally agreed upon that at $\mathrm{pH}>10$, monomeric $\mathrm{WO}_{4}{ }^{2-}$ is the only species in solution, ${ }^{40}$ and it has further been reported that at concentrations $<10 \mathrm{mM}$ (corresponding to $1.84 \mathrm{mg} \mathrm{W}$ $\mathrm{L}^{-1}$ ), no polyanions are formed in pure solution. ${ }^{41}$ However, our knowledge on the impact of time, $\mathrm{pH}$, and $\mathrm{W}$ concentration on the $\mathrm{W}$ condensation reaction is still inadequate, and even less is known about polymer formation of $\mathrm{W}$ with other elements. The majority of studies on $\mathrm{W}$ solution speciation was performed under narrow ranges of environmental conditions using mostly pure solution models that limit their applicability for complex environmental samples such as soils. $7,8,11,13,32-34$ Our results clearly demonstrate a strong $\mathrm{pH}$ effect on $\mathrm{W}$ polymerization in soil solution with the contribution of polymeric species to total soluble $\mathrm{W}$ strongly decreasing in $\mathrm{W}$ 5000 soils from acidic (46-68\%) to limed conditions (1517\%; Table 4 and Figure S2). Negligible or no W polymerization can be expected in the W 500 soil due to either the W concentrations being too low $\left(<0.01 \mathrm{mg} \mathrm{L}^{-1}\right.$, acidic soils) or soil $\mathrm{pH}$ being high (limed treatments).

Very little information is available on the toxicological effects of polytungsten species. In our study, for each $\mathrm{W}$ addition level ( 500 and $5000 \mathrm{mg} \mathrm{kg}^{-1}$ ), total soluble $\mathrm{W}$ concentrations were significantly higher in the high $\mathrm{pH}$ soils compared to the respective acidic counterpart (Table 2 and Figure S2). However, we observed lower biomass production accompanied by lower W shoot concentrations in the acidic W 5000 soils compared with the limed W 500 soils despite higher soil solution $\mathrm{W}$ concentrations (total $\mathrm{W}$ but also $<10 \mathrm{kDa}$ fraction) in the acidic W 5000 treatments (Figures $1 \mathrm{~A}$ and $2 \mathrm{~A}$ and Tables 2 and 4; for a direct data comparison of limed W 500 versus acidic W 5000, also see Figure S2). In addition, the absolute W soil solution concentrations of the different $\mathrm{W}$ polymer size fractions ( $<10 \mathrm{kDa}, 10-30 \mathrm{kDa}$, and $30 \mathrm{kDa}-0.45 \mu \mathrm{m}$; Table 4) revealed similar $W$ concentrations (milligrams per liter) in the monomeric and oligomer fraction $(<10 \mathrm{kDa})$ in the acidic W 5000 soils (Table 4). This not only explains the lack of differences in W plant uptake in the acidic W 5000 soils (in contrast to the limed W 5000 treatments) but also suggests that mainly monomeric and oligomeric $\mathrm{W}$ is taken up, with the 
latter having a greater phytotoxic effect on plant growth performance than monomeric W (Figures 1 and S2). This is further supported by the decreased nodulation (Figure 1) and lower accumulation of all other major nutrients in soybean shoots in the acidic W 5000 soils (Figure 4 and Table S1). On top of increased $\mathrm{W}$ phytotoxicity, $\mathrm{Ca}$ and micronutrient malnutrition may have contributed to reduced biomass production particularly in the acidic W 5000 sand soil (Figure 4 and Table 3). Interestingly, total plant $\mathrm{N}$ was only little affected by the presence of polymeric $\mathrm{W}$ species. In accordance with our results, Strigul et al. ${ }^{3}$ observed a significantly higher toxicity of sodium metatungstate $\left(3 \mathrm{Na}_{2} \mathrm{WO}_{4} \cdot 9 \mathrm{WO}_{3}\right)$ than of monomeric $\mathrm{W}\left(\mathrm{Na}_{2} \mathrm{WO}_{4}\right)$ for fish. Tajima ${ }^{42}$ also reported that polyoxotungstates nonspecifically inhibited several anionsensitive enzymes in Escherichia coli, probably as a result of the charge interaction by acting as nucleic acid analogues. Consequently, the overall negative effect of polymeric $\mathrm{W}$ on plant nutritional status may indicate a nonspecific inhibition of membrane transporter proteins resulting in a decreased nutrient uptake capacity.

We acknowledge that the analysis of $\mathrm{W}$ species in soils is highly challenging and that soil solutions for speciation analysis were obtained from saturated, unplanted soil. It therefore cannot be ruled out that $\mathrm{W}$ soil solution speciation might have been altered by the presence of soybean plants. Separation of $\mathrm{W}$ polymers with chromatographic methods is complicated by potential reactions of the analytes toward the (functionalized) surface of the chromatographic material involved as well as by species interconversion due to changes in $\mathrm{pH}$ or buffer conditions. Accordingly, size-exclusion chromatography (SEC) and ion chromatography are hampered by unwanted, nonspecific interaction of the $\mathrm{W}$ species with the stationary phase and by buffer $\mathrm{pH}$ leading to species interconversion, respectively. Bednar et al. ${ }^{43}$ attempted to separate and quantify polytungsten species in the soil solution of a $\mathrm{W}$ contaminated soil using SEC coupled with ICP-MS and direct infusion electrospray ionization mass spectrometry to identify $\mathrm{W}$ polymers; however, the simple act of sample acidification prior to analysis is likely to have caused changes in $\mathrm{W}$ speciation. Moreover, in-source adduct formation cannot be excluded in the electrospray process. Ogundipe et al. ${ }^{40}$ suggested that Raman spectroscopy or laser desorptionionization mass spectrometry combined with a time-of-flight mass spectrometry analyzer (LDI-TOF) as potentially suitable approaches, but so far, these techniques have not been successfully applied to complex environmental samples. In this situation, ultrafiltration represents a simple but effective alternative that can be used to verify the presence of $\mathrm{W}$ polymers in solution. Obtained results are free from artifacts as the method requires neither sample dilution nor acidification or buffering, and only inert surfaces come into contact with the sample; however, the ultra-centrifugation approach does not provide mass specific information about the investigated polymers.

Effect of $\mathrm{W}$ on Plant Nutrition Other than $\mathrm{N}$ and Mo. Plant nutrition typically changed with soil type and $\mathrm{pH}$; however, we observed mostly inconsistent effects on nutrient uptake in the different $\mathrm{W}$ treatments except for a general decrease in nutrient content in the acidic W 5000 soils and a trend for reduced shoot $\mathrm{Fe}, \mathrm{Cr}, \mathrm{Ni}$, and $\mathrm{Cu}$ at increasing $\mathrm{W}$ levels (Table 3 ). When grown in nutrient solution culture, Gerloff et al. ${ }^{44}$ observed a significant reduction in shoot $\mathrm{Fe}$ and leaf chlorosis in tomatoes due to increasing Mo concentrations.
Considering the chemical similarity of $\mathrm{W}$ and Mo, it is likely that $\mathrm{W}$ triggered the same antagonistic effects causing the observed reduction of shoot $\mathrm{Fe}$ in soybean in the current study. To the best of our knowledge, similar observations of a negative effect of $\mathrm{W}$ or $\mathrm{Mo}$ on $\mathrm{Cu}, \mathrm{Ni}$, and $\mathrm{Cr}$ plant tissue concentrations have not yet been reported. Molybdenum uptake was either not affected or negatively affected by the addition of $\mathrm{W}$ in the acidic soils, while a significant positive effect on Mo tissue concentrations was observed in the limed soils (except roots with limed W 500; Figure 2 and Table 3). This suggests that $\mathrm{W}$ successfully competes for the same sorption sites as Mo, resulting in an increase in Mo solubility, particularly at alkaline soil $\mathrm{pH}$, at which the anionic sorption strength decreased due to the deprotonation of mineral surfaces. Kumar and Aery ${ }^{33}$ observed the same trend of a concurrent increase of $\mathrm{W}$ and Mo uptake by wheat grown on an alkaline soil spiked with increasing $\mathrm{W}$ concentrations. These findings are supported by Gustafsson, ${ }^{10}$ who demonstrated a stronger sorption of $\mathrm{WO}_{4}{ }^{2-}$ than $\operatorname{did} \mathrm{MoO}_{4}{ }^{2-}$ to ferrihydrite.

Effect of pH-Dependent W Solubility and Soil Texture on Molybdoenzyme Activity and Plant N Nutrition. Due to its symbiosis with $\mathrm{N}_{2}$-fixing rhizobial bacteria, soybean can rely on both $\mathrm{NO}_{3}{ }^{-}$assimilation via $\mathrm{NR}$ as well as on the exchange of microbially fixed $\mathrm{N}_{2}$ (via nitrogenase) in the form of ureides for photosynthates in the form of sugars. In uncontaminated soils, high $\mathrm{NO}_{3}^{-}$concentrations were found to significantly reduce nodulation and symbiotic $\mathrm{N}_{2}$ fixation. ${ }^{45}$ Although we did not directly measure $\mathrm{NO}_{3}{ }^{-}$concentrations in our soils at the beginning of our experiments, our results indicate a difference of available $\mathrm{NO}_{3}{ }^{-}$concentrations affecting the observed patterns of molybdoenzyme activity. Generally, in legumes, nodulation and nif-gene abundance decline at high levels of available soil $\mathrm{N}$ due to high $\mathrm{C}$ investments of plants to nodules and the $\mathrm{N}_{2}$-fixation process, ${ }^{46}$ which only pays off under N-limiting conditions. Typically, sandy soils are more prone to $\mathrm{NO}_{3}{ }^{-}$leaching than clay soils, ${ }^{47}$ and nitrification was repeatedly shown to be inhibited under acidic conditions. ${ }^{48,49}$ Therefore, our data suggest a lower $\mathrm{NO}_{3}{ }^{-}$availability in the acidic sand control soil, resulting in a low NR activity that was overcompensated by high nodule biomass and high symbiotic $\mathrm{N}_{2}$ fixation (percent NdfA) (Figures $1 \mathrm{C}$ and 3B). Similar to other studies, a positive effect of enhanced nodulation on total plant $\mathrm{N}^{46}$ and biomass production was observed in the acidic sand soil control treatment (Figures 1 and 3C). Liming, however, is known to increase net nitrification, ${ }^{49}$ suggesting that a higher $\mathrm{NO}_{3}{ }^{-}$availability was responsible for the higher $\mathrm{NR}$ activity accompanied by a decrease in symbiotic $\mathrm{N}_{2}$ fixation (percent NdfA) in the limed sand soil control treatment (Figure 3A,B). We attribute the lack of differences in NR activity in the clay control soils to the stronger physical protection of soil organic matter by the high clay content against mineralization and nitrification. ${ }^{50}$

Despite its potential negative effect on eukaryotic life, ${ }^{32} \mathrm{~W}$, like Mo, is a bioelement but, however, not a universal one. All eukarya and most bacteria strictly depend on Mo; however, several archaea and some bacteria have been identified that either are strictly dependent on $\mathrm{W}$, have the ability to choose between $\mathrm{W}$ and Mo depending on the environmental conditions, or evolved to use Mo and W interchangeably for distinct functions. ${ }^{51}$ Nevertheless, a significant decrease in nitrogenase activity of several free living $\mathrm{N}_{2}$ fixing bacteria in the presence of $\mathrm{W}$ was reported. ${ }^{15,16,52}$ Although the exact toxicity mechanism is not known, it was suggested that a 
replacement of Mo by $\mathrm{W}$ renders the $\mathrm{N}_{2}$-fixing nitrogenase enzyme inactive. ${ }^{53}$ Also, the activity of nitrate reductase, a molybdoenzyme responsible for the assimilatory reduction of nitrate to nitrite, was repeatedly shown to be inhibited in the presence of monomeric tungstate with its negative effect again being attributed to the prevention of the formation of an active Mo cofactor required for NR catalytic activity. ${ }^{54-56}$ Deng et al. ${ }^{54}$ found that $\mathrm{W}$ inactivated NR but simultaneously increased NR protein abundance and corresponding mRNA tissue concentrations, leading to an over-expression of the NR genes. In our study, $\mathrm{W}$ had contrasting effects on the interrelated activities of the studied molybdoenzymes (i.e., nitrate reductase, and nitrogenase, respectively) in nodulated soybeans, indicating complex interactions between $(\mathrm{pH}$ dependent) $\mathrm{W}$ solubility and speciation, $\mathrm{pH}$ and texture-driven organic $\mathrm{N}$ mineralization and stabilization, and molybdoenzyme-driven plant $\mathrm{N}$ nutrition. Irrespective of $\mathrm{W}$ addition, $\mathrm{NR}$ activity in the control soils was negatively related to nodule biomass $(r=0.55, p<0.05$; Figures 1 and 3$)$. However, excluding the limed W 5000 treatment and the acidic W 5000 sand, soybean plants managed to maintain biomass production and $\mathrm{N}$ acquisition at or even above (acidic W 500 clay) control levels (Figures 1 and $3 \mathrm{C}$ ). This suggests that a W-driven loss of NR functionality can be compensated by increasing nodulation (Figure 1C) and enhanced symbiotic $\mathrm{N}_{2}$ fixation activity (Figure 3B,D; acidic W 5000 clay). Compensation of decreased NR activity by enhancing nodule biomass was particularly observed in the limed soils with intermediate $\mathrm{W}$ contamination (500 $\mathrm{mg} \mathrm{W} \mathrm{kg}^{-1}$ ). Nodulation and, therefore, symbiotically derived plant $\mathrm{N}$ (percent $\mathrm{NdfA}$ ) as well were more strongly enhanced in the limed W 500 clay soil compared to the limed W 500 sand soil (Figure 3B), presumably due to higher N mineralization rates in the limed sand soils due to a weaker protection of soil organic matter compared to the clay soil. ${ }^{50}$ Growing soybean in hydroponics at high nitrate availability, Harper $^{57}$ also observed an increase in nodulation alongside with enhanced acetylene reduction activity (i.e., a measure for $\mathrm{N}_{2}$ fixation activity) in the presence of up to $300 \mu \mathrm{M}$ sodium tungstate $\left(\mathrm{Na}_{2} \mathrm{WO}_{4}\right)$, followed by a slight decline at $400 \mu \mathrm{M}$ $\mathrm{Na}_{2} \mathrm{WO}_{4}$ (corresponding to $74 \mathrm{mg} \mathrm{W} \mathrm{L}{ }^{-1}$ ). No corresponding $\mathrm{N}$ and $\mathrm{W}$ tissue concentrations were reported in this study. In accordance with this study, ${ }^{57}$ our results also suggest that nitrate assimilation (NR activity) is more strongly inhibited by increasing $\mathrm{W}$ concentrations than is symbiotic $\mathrm{N}_{2}$ fixation until $\mathrm{W}$ concentrations become too toxic and inhibit nodule formation. Considering that $\mathrm{W}$ concentrations were about 3 times higher in nodules than in shoots at W 500 (Figure 2), this indicates a higher tolerance or better detoxification mechanism in the symbiosomes.

In contrast to intermediate $\mathrm{W}$ levels, the high contribution of polymeric W species in the acidic W 5000 soils (48-68\% 10 $\mathrm{kDa}-0.45 \mu \mathrm{m})$ and the extremely high concentrations of monomeric and oligomeric $\mathrm{W}$ in the corresponding limed treatments $(83-85 \%<10 \mathrm{kDa}$; Table 4) drastically reduced (acidic soils) or completely inhibited nodule formation (limed soils; Figure 1C). However, in one treatment (acidic W 5000 clay soil), the nodule fixation activity (grams of nitrogen fixed per gram of nodule dry weight) was strongly increased in the presence of high $\mathrm{W}$ concentrations, keeping the total plant $\mathrm{N}$ accumulation at control levels (Figure 3B,D). Unlike the acidic W 5000 sand soil, NR activity was particularly low in this treatment, with levels comparable with the plants in the limed W 5000 soils that died after 3 weeks of soil growth (Figure 3A).
Unfortunately, nodule biomass in the acidic W 5000 clay soil was insufficient for reliable analysis of $\mathrm{W}$ concentration in nodule tissue (Figure 2C). Consequently, we can only speculate whether or not the differences in $\mathrm{N}_{2}$-fixation activity between acidic W 5000 sand and clay soils were triggered by the extremely low NR activity or caused by differences in W nodule tissue concentrations. W speciation in soil solution (Table 4, monomeric and oligomeric fraction of $<10 \mathrm{kDa}$ ) as well as root and shoot $\mathrm{W}$ tissue concentrations suggest comparable W accumulation in nodules in the acidic W 5000 sand and clay soils (Figure 2); however, soil-specific differences in the $\mathrm{W}$ polymer structure and composition and, thus, toxicity cannot be ruled out.

Even though previous studies reported negative effects of $\mathrm{W}$ on nitrogenase activity of free-living $\mathrm{N}_{2}$-fixing bacteria, a higher nitrogenase abundance in the few nodules formed, a different $\mathrm{W}$-species-dependent compartmentalization and detoxification mechanism, or both could have offset the effect of W-blocked nitrogenase enzymes. This could explain the increase in nodule fixation activity in the acidic W 5000 clay soil that kept total plant $\mathrm{N}$ comparable with the respective control levels (Figure 3C,D); however, direct evidence for the proposed mechanisms is lacking. Low $\mathrm{N}$ availability as well as Mo deficiency have been found to induce relocation of the intermediately phloem mobile Mo from shoots to nodules. ${ }^{58}$ It remains unclear whether increased nodule Mo was simply a result of increased solubility (liming effect and competitive desorption by W), W-induced $\mathrm{N}$ deficiency triggered preferential transport of Mo (and, mistakenly, $\mathrm{W}$ as well) into nodule tissue to maintain $\mathrm{N}_{2}$ fixation at a sufficient level, or a combination of both. Nevertheless, shoot Mo remained above the critical concentration $\left(0.1-1 \mathrm{mg} \mathrm{kg}^{-1}\right)^{59}$ for plant development in all treatments, clearly demonstrating that the reduction of NR activity was a direct effect of the increasing presence of $\mathrm{W}$ in the plant tissue rather than insufficient shoot Mo supply. Pandey et al. ${ }^{15}$ showed that the inhibitory effect of $\mathrm{W}$ on $\mathrm{N}_{2}$ fixation of free-living Plectonema boryanum was less-pronounced under Mo-sufficient than Mo-deficient conditions. Taking all of this together, our results highlight the importance of taking soil $\mathrm{pH}$ into consideration when conducting risk assessment studies of $\mathrm{W}$ in the plant-soil environment, which has been largely neglected in the past.

\section{ASSOCIATED CONTENT}

\section{S Supporting Information}

The Supporting Information is available free of charge on the ACS Publications website at DOI: 10.1021/acs.est.7b06500.

Figures and details on $\mathrm{W}$ and nutrient analysis by ICPMS and ICP-OES, the cytosolic nitrate reductase assay, and plant $\delta^{15} \mathrm{~N}$ analysis. Tables showing all nutrient concentrations analyzed in root, shoot, and nodule tissue including statistical results and Mo tissue concentrations including results from statistical comparison across the different tissue types within each soil treatment. A figure highlighting the effect of $\mathrm{pH}$ dependent $\mathrm{W}$ bioavailability and speciation on biomass production and $\mathrm{W}$ uptake by soybeans. (PDF)

\section{AUTHOR INFORMATION}

\section{Corresponding Author}

*E-mail: eva.oburger@boku.ac.at. 


\section{ORCID}

Eva Oburger: 0000-0003-3213-2588

Stephan Hann: 0000-0001-5045-7293

\section{Notes}

The authors declare no competing financial interest.

\section{ACKNOWLEDGMENTS}

This study was funded by the Austrian Science Fund (FWF), grant no. P 25942-N28. Carolina Vergara Cid was funded by the Ernst Mach Grant from the Austrian Federal Ministry of Education, Science and Research. We thank Daniel Schwertberger, Veronika Slavik, and Margarete Watzka for their support with sample preparation and analysis. Dr. Peter Hoedel from S4Science Austria is acknowledged for financial support regarding the ICP-MS measurements.

\section{REFERENCES}

(1) Koutsospyros, A. D.; Strigul, N.; Braida, W.; Christodoulatos, C. Tungsten: Environmental Pollution and Health Effects A2 - Nriagu, J.O. In Encyclopedia of Environmental Health; Elsevier: Burlington, MA, 2011; pp 418-426.

(2) Koutsospyros, A.; Braida, W.; Christodoulatos, C.; Dermatas, D.; Strigul, N. A review of tungsten: from environmental obscurity to scrutiny. J. Hazard. Mater. 2006, 136 (1), 1-19.

(3) Strigul, N.; Koutsospyros, A.; Christodoulatos, C. Tungsten speciation and toxicity: Acute toxicity of mono- and poly-tungstates to fish. Ecotoxicol. Environ. Saf. 2010, 73 (2), 164-171.

(4) Charter, R. A.; Tabatabai, M. A.; Schafer, J. W. Arsenic, molybdenum, selenium and tungsten contents of fertilizers and phosphate rocks. Commun. Soil Sci. Plant Anal. 1995, 26 (17-18), 3051-3062.

(5) Clausen, J. L.; Korte, N. Environmental fate of tungsten from military use. Sci. Total Environ. 2009, 407 (8), 2887-93.

(6) Sen, I. S.; Peucker-Ehrenbrink, B. Anthropogenic Disturbance of Element Cycles at the Earth's Surface. Environ. Sci. Technol. 2012, 46 (16), 8601-8609.

(7) Kennedy, A. J.; Johnson, D. R.; Seiter, J. M.; Lindsay, J. H.; Boyd, R. E.; Bednar, A. J.; Allison, P. G. Tungsten Toxicity, Bioaccumulation, and Compartmentalization into Organisms Representing Two Trophic Levels. Environ. Sci. Technol. 2012, 46 (17), 9646-9652.

(8) Lin, C. Y.; Li, R. P.; Cheng, H. G.; Wang, J.; Shao, X. Tungsten Distribution in Soil and Rice in the Vicinity of the World's Largest and Longest-Operating Tungsten Mine in China. PLoS One 2014, 9 (3), 8. (9) Bednar, A. J.; Boyd, R. E.; Jones, W. T.; McGrath, C. J.; Johnson, D. R.; Chappell, M. A.; Ringelberg, D. B. Investigations of tungsten mobility in soil using column tests. Chemosphere 2009, 75 (8), 10491056.

(10) Gustafsson, J. P. Modelling molybdate and tungstate adsorption to ferrihydrite. Chem. Geol. 2003, 200 (1-2), 105-115.

(11) Bamford, J. E.; Butler, A. D.; Heim, K. E.; Pittinger, C. A.; Lemus, R.; Staveley, J. P.; Lee, K. B.; Venezia, C.; Pardus, M. J. Toxicity of sodium tungstate to earthworm, oat, radish, and lettuce. Environ. Toxicol. Chem. 2011, 30 (10), 2312-8.

(12) Mendel, R. R. The Molybdenum Cofactor. J. Biol. Chem. 2013, 288 (19), 13165-13172.

(13) Jiang, X. Y.; Omarov, R. T.; Zhazira Yesbergenova, S.; Sagi, M. The effect of molybdate and tungstate in the growth medium on abscisic acid content and the Mo-hydroxylases activities in barley (Hordeum vulgare L.). Plant Sci. 2004, 167 (2), 297-304.

(14) Jiang, F.; Heilmeier, H.; Hartung, W. Abscisic acid relations of plants grown on tungsten enriched substrates. Plant Soil 2007, 301 (1), 37-49.

(15) Pandey, K. D.; Sukla, S.; Naz, S.; Smita, C.; Kumar, K. A. Nitrogenase derepression and associated metabolism in a microaerophilic cyanobacterium, Plectonema boryanum. J. Microbiol. Biotechnol. 2001, 11 (2), 179-185.
(16) Kletzin, A.; Adams, M. W. W. Tungsten in biological systems. FEMS Microbiol. Rev. 1996, 18 (1), 5-63.

(17) Smolders, E.; Oorts, K.; Van Sprang, P.; Schoeters, I.; Janssen, C. R; McGrath, S. P.; McLaughlin, M. J. Toxicity of Trace Metals in Soil as Affected by Soil Type and Aging After Contamination: Using Calibrated Bioavailability Models to Set Ecological Soil Standards. Environ. Toxicol. Chem. 2009, 28 (8), 1633-1642.

(18) Austrian Standards. Chemical analyses of soils - Determination of acidity ( $\mathrm{pH}$ value) ÖNORM L 1083; Austrian Standards: Vienna, Austria, 1999.

(19) Loeppert, R. H.; Inskeep, W. P. Iron. In Methods of Soil Analysis Part 3-Chemical Methods, Sparks, D. L.; Page, A. L.; Helmke, P. A.; Loeppert, R. H., Eds; Soil Science Society of America, American Society of Agronomy: Madison, WI, 1996; pp 639-664.

(20) Austrian Standards. Chemical analyses of soils - Determination of exchangeable cations and of effective cation exchange capacity (CECeff) by extraction with bariumchloride solution ÖNORML 1086-1; Austrian Standards: Austria, Vienna, 2000.

(21) Argaw, A. Symbiotic effectiveness of inoculation with Bradyrhizobium isolates on soybean [Glycine max (L.) Merrill] genotypes with different maturities. SpringerPlus 2014, 3 (1), 753.

(22) Qu, L.; Huang, Y.; Zhu, C.; Zeng, H.; Shen, C.; Liu, C.; Zhao, Y.; Pi, E. Rhizobia-inoculation enhances the soybean's tolerance to salt stress. Plant Soil 2016, 400 (1), 209-222.

(23) Deaker, R.; Roughley, R. J.; Kennedy, I. R. Legume seed inoculation technology: a review. Soil Biol. Biochem. 2004, 36 (8), $1275-1288$.

(24) Fehr, W. R.; Caviness, C. E. Agricultural, I. S. C.; Station, H. E. E.; Service, I. S. U. C. E., Stages of Soybean Development; Cooperative Extension Service; Agriculture and Home Economics Experiment Station, Iowa State University of Science and Technology: Ames, IA, 1977.

(25) Pöykiö, R.; Torvela, H.; Perämäki, P.; Kuokkanen, T.; Rönkkömäki, H. Comparison of dissolution methods for multielement analysis of some plant materials used as bioindicator of sulphur and heavy metal deposition determined by ICP-AES and ICPMS. Analusis 2000, 28 (9), 850-854.

(26) Sanderson, G. W.; Cocking, E. C. Enzymic Assimilation of Nitrate in Tomato Plants. II. Reduction of Nitrite to Ammonia. Plant Physiol. 1964, 39 (3), 423-431.

(27) Stöhr, C.; Wienkoop, S.; Ullrich, W. R. Nitrate reductase in roots: Succinate- and NADH-dependent plasma membrane-bound forms. In Recent Advances of Plant Root Structure and Function: Proceedings of the 5th International Symposium on Structure and Function of Roots. Stará Lensná, Slovakia, 30 August - 4 September, 1998, Gašparíková, O.; Čiamporová, M.; Mistrík, I.; Baluška, F., Eds; Springer Netherlands: Dordrecht, The Netherlands, 2001; pp 119122.

(28) Wanek, W.; Arndt, S. K. Difference in delta N-15 signatures between nodulated roots and shoots of soybean is indicative of the contribution of symbiotic N-2 fixation to plant N. Journal of Experimental Botany 2002, 53 (371), 1109-1118.

(29) Schenkeveld, W. D. C.; Kimber, R. L.; Walter, M.; Oburger, E.; Puschenreiter, M.; Kraemer, S. M. Experimental considerations in metal mobilization from soil by chelating ligands: The influence of soil-solution ratio and pre-equilibration - A case study on $\mathrm{Fe}$ acquisition by phytosiderophores. Sci. Total Environ. 2017, 579, $1831-1842$.

(30) Di Rienzo, J. A.; Guzman, A. W.; Casanoves, F. A multiplecomparisons method based on the distribution of the root node distance of a binary tree. Journal of Agricultural, Biological, and Environmental Statistics 2002, 7 (2), 129-142.

(31) INFOSTAT, Di Rienzo, J. A.; Casanoves, F.; Balzarini, M. G.; Gonzalez, L.; Tablada, M.; Robledo, C. W. InfoStat versión 2011; Grupo InfoStat, FCA, Universidad Nacional de Córdoba: Argentina, 2011.

(32) Strigul, N.; Koutsospyros, A.; Arienti, P.; Christodoulatos, C.; Dermatas, D.; Braida, W. Effects of tungsten on environmental systems. Chemosphere 2005, 61 (2), 248-258. 
(33) Kumar, A.; Aery, N. C. Effect of tungsten on growth, biochemical constituents, molybdenum and tungsten contents in wheat. Plant, Soil Environ. 2011, 57 (11), 519-525.

(34) Johnson, D. R.; Inouye, L. S.; Bednar, A. J.; Clarke, J. U.; Winfield, L. E.; Boyd, R. E.; Ang, C. Y.; Goss, J. Tungsten bioavailability and toxicity in sunflowers (Helianthus annuus L.). Land Contamination \& Reclamation 2009, 17 (1), 141-151.

(35) Strigul, N.; Koutsospyros, A.; Arienti, P.; Christodoulatos, C.; Dermatas, D.; Braida, W. Effects of tungsten on environmental systems. Chemosphere 2005, 61 (2), 248-58.

(36) Davies, E. B.; Stockdill, S. M. J. A Pasture Response to Sodium Tungstate on a New Zealand Soil. Nature 1956, 178, 866.

(37) Barrow, N. J. The four laws of soil chemistry: the Leeper lecture 1998. Aust. J. Soil Res. 1999, 37 (5), 787-830.

(38) Hur, H.; Reeder, R. J. Tungstate sorption mechanisms on boehmite: Systematic uptake studies and X-ray absorption spectroscopy analysis. J. Colloid Interface Sci. 2016, 461, 249-260.

(39) Strigul, N. Does speciation matter for tungsten ecotoxicology? Ecotoxicol. Environ. Saf. 2010.73109910.1016/j.ecoenv.2010.05.005

(40) Ogundipe, A.; Pavlov, J.; Braida, W.; Koutsospyros, A.; Sen, G.; Christodoulatos, C.; O'Connor, G. Evaluation of analytical methods to adress tungsten speciation. Global Nest Journal 2009, 11 (3), 308-317.

(41) Ng, K. Y. S.; Gulari, E. Spectroscopic and scattering investigation of isopoly- molybdate and tungstate solutions. Polyhedron 1984, 3 (8), 1001-1011.

(42) Tajima, Y. The effects of tungstophosphate and tungstosilicate on various stress promoters transformed in Escherichia coli. J. Inorg. Biochem. 2003, 94 (1-2), 155-160.

(43) Bednar, A. J.; Kirgan, R. A.; Johnson, D. R.; Russell, A. L.; Hayes, C. A.; McGrath, C. J. Polytungstate analysis by SEC-ICP-MS and direct-infusion ESI-MS. Land Contamination \& Reclamation 2009, 17 (1), 129-137.

(44) Gerloff, G. C.; Stout, P. R.; Jones, L. H. P. Molybdenum manganese - iron antagonisms in the nutrition of tomato plants. Plant Physiol. 1959, 34 (6), 608-612.

(45) George, T.; Ladha, J. K.; Buresh, R. J.; Garrity, D. P. Managing native and legume-fixed nitrogen in lowland rice-based cropping systems. In Biological Nitrogen Fixation for Sustainable Agriculture: Extended versions of papers presented in the Symposium, Role of Biological Nitrogen Fixation in Sustainable Agriculture at the 13th Congress of Soil Science, Kyoto, Japan, 1990, Ladha, J. K.; George, T.; Bohlool, B. B., Eds.; Springer Netherlands: Dordrecht, The Netherlands, 1992; pp 69-91.

(46) Cooper, J. E.; Scherer, H. W. Chapter 16 - Nitrogen Fixation A2 - Marschner, Petra. In Marschner's Mineral Nutrition of Higher Plants, 3rd ed.; Academic Press: San Diego, CA, 2012; pp 389-408.

(47) Barker, A.; Bryson, G. Nitrogen. In Handbook of Plant Nutrition; CRC Press: Boca Raton, FL, 2006; pp 21-50.

(48) Cheng, Y.; Wang, J.; Mary, B.; Zhang, J.-b.; Cai, Z.-c.; Chang, S. $\mathrm{X}$. Soil $\mathrm{pH}$ has contrasting effects on gross and net nitrogen mineralizations in adjacent forest and grassland soils in central Alberta, Canada. Soil Biol. Biochem. 2013, 57, 848-857.

(49) Ste-Marie, C.; Paré, D. Soil, pH and N availability effects on net nitrification in the forest floors of a range of boreal forest stands. Soil Biol. Biochem. 1999, 31 (11), 1579-1589.

(50) Hassink, J.; Bouwman, L. A.; Zwart, K. B.; Bloem, J.; Brussaard, L. Relationships between soil texture, physical protection of organic matter, soil biota, and $\mathrm{c}$ and $\mathrm{n}$ mineralization in grassland soils. Geoderma 1993, 57 (1), 105-128.

(51) Bevers, L. E.; Hagedoorn, P.-L.; Hagen, W. R. The bioinorganic chemistry of tungsten. Coord. Chem. Rev. 2009, 253 (3), 269-290.

(52) Hallenbeck, P. C.; Benemann, J. R. Effect of molybdenum starvation and tungsten on the synthesis and activity of nirtrogenase in Anabaena cylindrica. FEMS Microbiol. Lett. 1980, 9 (2), 121-124.

(53) Ringelberg, D. B.; Reynolds, C. M.; Winfield, L. E.; Inouye, L. S.; Johnson, D. R.; Bednar, A. J. Tungsten Effects on Microbial Community Structure and Activity in a Soil. J. Environ. Qual. 2009, 38 (1), 103-110.
(54) Deng, M. D.; Moureaux, T.; Caboche, M. Tungstate, a molybdate analog inactivating nitrate reductase, deregulates the expression of the nitrate reductasestructural gene. Plant Physiol. 1989, 91 (1), 304-309.

(55) Xiong, J.; Fu, G.; Yang, Y.; Zhu, C.; Tao, L. Tungstate: is it really a specific nitrate reductase inhibitor in plant nitric oxide research? J. Exp. Bot. 2012, 63 (1), 33-41.

(56) Saroop, S.; Chanda, S. V.; Singh, Y. D. Effect of phytohormones and tungsten on light-induced and nitrate-induced nitrate reductase activity of mustard cotyledons. Acta Physiol. Plant. 2000, 22 (4), 465469.

(57) Harper, J. E.; Nicholas, J. C. Nitrogen Metabolism of Soybeans: I. Effect of Tungstate on Nitrate Utilization, Nodulation, and Growth. Plant Physiol. 1978, 62 (4), 662-664.

(58) Brodrick, S. J.; Giller, K. E. Root nodules of Phaeseolus - efficient scavengers of molybdenum for $\mathrm{N}_{2}$ fixation. J. Exp. Bot. 1991, 42 (238), 679-686.

(59) Broadley, M.; Brown, P.; Cakmak, I.; Rengel, Z.; Zhao, F. Chapter 7. Function of Nutrients: Micronutrients A2 - Marschner, Petra. In Marschner's Mineral Nutrition of Higher Plants, 3rd ed.; Academic Press: San Diego, CA, 2012; pp 191-248. 